\title{
Didactic Games in Social Studies in Primary School
}

\author{
Polona Jančič, Vlasta Hus \\ Faculty of Education, University of Maribor, Maribor, Slovenia \\ Email:polona.jancic1@um.si,vlasta.hus@um.si
}

How to cite this paper: Jančič, P., \& Hus, V. (2017). Didactic Games in Social Studies in Primary School. Creative Education, 8, 1892-1902.

https://doi.org/10.4236/ce.2017.812129

Received: July 24, 2017

Accepted: September 24, 2017

Published: September 27, 2017

Copyright (C) 2017 by authors and Scientific Research Publishing Inc. This work is licensed under the Creative Commons Attribution International License (CC BY 4.0).

http://creativecommons.org/licenses/by/4.0/

\section{(c) (†) Open Access}

\begin{abstract}
This study attempts to present representation of didactic games in social studies classes in primary school. We were especially interested in origin of didactic games that teacher use. Didactic game is a game used in classes taught with game-based learning and is proven to be an effective experiential learning method in more researches by Boocock, Bognar and others. In March and April 2017, we conducted a research among the 290 students of the $4^{\text {th }}$ and $5^{\text {th }}$ grade and 177 teachers teaching $4^{\text {th }}$ and $5^{\text {th }}$ grade about the representation of didactic games in wider aspects in the $4^{\text {th }}$ and $5^{\text {th }}$ grade of social studies classes in Slovenian primary schools. In addition, 56 social studies lessons were observed. Results revealed that there is a problem of insufficient range of ready-to-use or ready-made games designed for the subject social studies, therefore the majority of teachers had already created a didactic game by themselves.
\end{abstract}

\section{Keywords}

Primary School, Learning, Games, Didactics, Social Studies

\section{Introduction}

In recent decades, the interest in games in classroom has increased. Boocock (1972) as in Bognar (1987), Roskos \& Christie (2000), Ginsburg (2007), Cenčič et al. (2008), Miller \& Almon (2009) and Juriševič (2012) are only some of the authors that have researched the effects of didactic game on teaching and learning among different age groups of children and on different educational stages. Positive effects have been proven on different stages, therefore there is no doubt didactic games are a desired and useful part of teaching process. In this article, we focus on the origin of didactic games. In our research, we observed insufficient range of Slovenian didactic games for social studies, therefore we were in- 
terested in the origin of didactic games or its concept. In the article, we present a part of a wider research about didactic games in social studies related to the origin of didactic games. First, we present the subject of social studies in Slovenian primary schools, explain the theory of didactic games and, lastly, present the research with its results and discussion.

\subsection{Social Studies in Slovenian Primary School}

In Slovenia social studies is a class that students encounter in the $4^{\text {th }}$ and $5^{\text {th }}$ grades of primary school. It includes goals from the fields of geography, sociology, history, ethnology, psychology, economy, politics, ethics, aesthetics and ecology.

In this course, students develop:

- understanding of their social, cultural and natural environment in time and space;

- awareness of the interaction, the interdependence of cultural, social, natural processes and phenomena and the importance of sustainable development;

- social, communication and research skills and abilities that besides knowledge enable them to effectively perform in the environment;

- attitudes and values in the context of environmental, civic and patriotic education and education for democracy and human rights;

- cognitive, emotional and social abilities, and skills and strategies of lifelong learning.

A total of 175 hours of class time are dedicated to it -70 in the $4^{\text {th }}$ grade and 105 in the $5^{\text {th }}$ grade. The didactic recommendations for the teaching of the subject social studies suggest that teachers should derive from students' prior knowledge, skills and interests, and take into account their individual potentials when they plan lessons (Budnar et al., 2011). From the content of curriculum for the subject of social studies we can conclude that is based on and comes from the constructivist theory of learning and teaching. The constructivist approach emphasises students' active roles in the education process, as well as their capability of developing their own knowledge by themselves based on experience and previous knowledge. A major element of constructivism is stimulating children's reasoning through active methods of instruction. As children grow and develop, concepts of how to acquire and organise information in their minds become more complex. The methods, forms and didactic strategies that are to be used in social studies lessons must be suitably combined with regard to the students' ages, characteristics, goals of the lessons and circumstances (Martin, 2001; Maxim, 2010; Naude, Bergh, \& Kruger, 2014). In the national curriculum for teaching social studies is among others a recommended didactic strategy experiential learning (Budnar et al., 2011).

\subsection{Experiential Learning}

The importance of the active involvement of children in the learning process is 
emphasised by several studies, namely by the following authors: Pianta, Laparo, \& Hamre (2006); Leavers (2005) and the study NICHD Early Child Care Research Network (2003; 2005) (as in Tankersley et al., 2013). A key element of experiential learning is a student, and the knowledge is a result of being personally involved in this pedagogical approach (Wurdinger \& Carlson, 2010).

Experiential learning is a teaching and learning strategy which attempts to connect the emotional and sensory experience of the students and their thinking into a whole (Marentič Požarnik, 2003). There is a broader selection of methods teachers can choose from in order to derive experiential teaching and learning strategy.

\subsection{Didactic Games}

In our study we are presenting one of possible methods supporting experiential learning. Tomič (1999) considers didactic game to be one of the methods of experiential leaning. There were a few researches made to prove that children learn best through play. Their findings were among other that play positively supports children's social/emotional, physical, cognitive and language skills and is essential to a child's overall healthy development (Boocock, 1972 as in Bognar, 1987; Ginsburg, 2007). Smith \& Simon (1984) researched that game enhances students' creativity and problem-solving. Sawyer (2001) explains that students who engage in social and dramatic game are in a greater extent able to take others' perspectives and are viewed as more intellectually and socially competent by their teachers. And Bodrova \& Leong (2007) interpreted that game contributes to the development of self-regulation and social skills such as turn-taking, collaboration and following rules, empathy, and motivation.

Didactic games can be classified by quite some authors. We are presenting classification that is based on Smilansky's (1968) classification of play and we adapted it to didactic games classification which is also presented by authors Bognar (1987) and Marjanovič Umek \& Zupančič (2001). Didactic games can be classified in constructive games, which emerge as children gain more experience playing with materials and begin to construct things, role-playing (simulation) games, with which we present an event, activity or situation from real life and games with rules, which have rules that students must take into account. The didactic games with rules are the following: different versions of domino, lottery, bingo, card games, Ludo games, physical games, music games etc.

\section{Methodology}

\subsection{Purpose of the Study}

The purpose of the study was to examine frequency of use if didactic games in social studies and origin of this games. In order to best explain use of didactic games in social studies we were interested in popularity of didactic games among students and frequency of different types of used didactic games. We were especially interested where teachers acquire didactic games or maybe they even made 
them by themselves. Given that we wanted to get an accurate overview of the situation, we upgraded our quantitative research by observing teaching in practice, since only then we were able to get a realistic picture of the use of games, and not just teachers' self-assessment.

We examined:

- popularity of didactic games with students;

- the frequency of types of didactic games in social studies;

- the origin of didactic games to be used in social studies.

\subsection{The Basic Research Method}

The study was based on a descriptive and casual non-experimental method of empirical research. Since we didn't plan to implement any pedagogical experiment at this first phase of research, the most appropriate research method was descriptive statistical method of empirical research.

\subsection{Sample}

We included a random sample of 177 Slovenian primary school teachers teaching social studies in the fourth or fifth grades in the academic year 2016/2017 and a random sample of 290 students enrolled in the fourth or fifth grade in the same academic year. In the research sample were included teachers and students from all Slovenian regions. The number of teachers selected for the convenience sample, was 56.

The research sample of 290 students consists of $56.6 \%$ in the fourth grade (164 students) and $43.4 \%$ (126 students) from the fifth grade. The sample is comprised of $53.1 \%$ boys ( 154 students) and $46.9 \%$ girls (136 students).

In a sample of 177 teachers who participated in the survey, 53\% taught in the school year 2016/17 in the fourth grade, and $47 \%$ taught in the fifth grade. The survey was completed mostly by teachers who have more than 20 years of service, i.e. $61 \%$. Of the remainder, $25 \%$ have taught from 11 to 20 years, and $14 \%$ have taught up to 10 years. Nine percent of the teachers were beginners with no title, $31 \%$ were mentors, and $55 \%$ were consultants. The least percentage in the sample, $5 \%$, were teacher counsellors. As for location, $53 \%$ of the participating teachers teach in urban primary schools and $47 \%$ teach in rural primary schools.

\subsection{Instrument}

Data for all variables were collected using two questionnaires. The first questionnaire was prepared for the social studies teachers of the fourth and fifth grade of Slovenian primary schools and was made up of different types of questions-from dichotomous questions to the ranking of answers. The second questionnaire was filled in by the students and it was easy to understand since it consisted of simple questions of choice.

Data was also obtained from class observation, i.e. observing performance of teachers. For this purpose, we assembled an observation protocol with which we 
wanted to gain the number of social studies lessons in which teachers carried out game-based learning and used games features.

Questionnaires for collecting all data had verified metric characteristics (validity, reliability, and objectivity). We ensured validity with reviewing and pre-testing our questionnaire on a sample. Reliability was controlled from the start of creating questions, since we were careful to provide detailed instructions and unambiguous specific questions. Objectivity was controlled with the selection of closed questions, which cannot be changed with the subjective assessments of information. Objectivity of the instrument was based on individual interviewing without the presence of assessor. The questionnaire consisted of various types of questions: dichotomous and closed-ended.

\subsection{Data Collection}

The data were acquired in March 2017 and partially in the first week of April 2017. The surveys for students were printed out and taken to randomly selected primary schools, where school management was asked to enable us to conduct the survey. We acquired 290 fully completed surveys. On this occasion, we also distributed surveys to their teachers. The survey for teachers was also prepared in an online form and sent to e-mail addresses of teachers throughout Slovenia as well as spread on the social media. We received back 177 fully completed questionnaires. We observed 56 classes.

\subsection{Data Analysis}

The data obtained from the questionnaire were analysed using the SPSS (version 21) statistics programme. For data processing, we used basic descriptive statistics, frequency distribution, and a non-parametrical Chi-Square test for independence. During the analysis, we also checked for statistically relevant differences between participating teachers with regard to teachers' working age, teachers' professional title, the grade teachers are teaching, the teaching environment (urban or rural primary school), and the teachers' attitudes towards teaching social studies. The difference between the groups was considered statistically significant if the degree of risk for the validity of the null hypothesis was less than $5 \%(p<0.05)$. The level at which the null hypothesis is rejected is usually set as 5 or fewer times out of 100 . The 0.05 probability level was historically an arbitrary choice which led to a trend to report test statistics as being significant at the $p<0.05$ and is acceptable as a reasonable choice in most social studies researches nowadays (Cramer \& Howitt, 2004; Field, 2013).

\section{Results}

\subsection{Popularity of Didactic Games with Students}

First we asked students which is for them the most favourite method for learning Social Studies. Students were offered an array of learning methods: learning with teacher's explanation, learning individually, learning through textbooks and 
workbooks, learning outside classroom and learning with didactic games. Table 1 shows that their answers were quite divided.

$30.7 \%$ of students responded that they prefer learning through a textbook and workbook. $25.2 \%$ of students responded that they prefer frontal lessons, i.e. that content is explained by their teacher. $17.2 \%$ of the students preferably learn individually so that they only read and learn the content. $3.4 \%$ of students prefer to learn outside, with lessons outside the classroom. $23.4 \%$ of students prefer learning through play.

Additional tests ( $\chi^{2}$-tests) showed that there are no statistically significant differences in regard to students' gender and grade.

\subsection{Use of Didactic Games in Social Studies Regarding the Type of Didactic Game}

Table 2 shows that teachers in social studies classes use didactic games rarely. Most commonly they use role-playing games $(\bar{x}=2.4)$, which is followed by games with rules $(\bar{x}=2.3)$, and most rarely they use constructive games $(\bar{x}=$ 1.7). There are no statistically significant differences between the responses of teachers depending on the environment of teaching, working years and professional title. In regards to the grade teachers are teaching we detected a statistically significant difference with role-playing games.

Statistically, the difference can be detected on the frequency of use of role-playing games depending on the grade $\left(\chi^{2}=8.597, \mathrm{~g}=2, \mathrm{P}=0.014\right)$. As presented in Table 3 , teachers who teach in the $4^{\text {th }}$ grade use statistically significant more role-playing games in social studies than teachers in the $5^{\text {th }}$ grade.

Table 1. Frequency of student's most favourite method for learning social studies.

\begin{tabular}{ccc}
\hline Answers & $\mathrm{f}$ & $\mathrm{f} \%$ \\
\hline With teachers explanation. & 73 & $25.2 \%$ \\
Learning individually. & 50 & $17.2 \%$ \\
Through textbooks and workbooks. & 89 & $30.7 \%$ \\
Learning outside classroom. & 10 & $3.4 \%$ \\
With didactic games. & 68 & $23.4 \%$ \\
Total & 290 & $100.0 \%$ \\
\hline
\end{tabular}

Table 2. Frequency of use of different types of games in social studies.

\begin{tabular}{cccccc}
\hline \multicolumn{5}{c}{ Frequency of use of different types of games } \\
\hline Types of games & $\begin{array}{c}\text { Never } \\
\mathrm{f}(\mathrm{f} \%)\end{array}$ & $\begin{array}{l}\text { Rarely } \\
\mathrm{f}(\mathrm{f} \%)\end{array}$ & $\begin{array}{c}\text { Frequently } \\
\mathrm{f}(\mathrm{f} \%)\end{array}$ & $\begin{array}{c}\text { Total } \\
\mathrm{f}(\mathrm{f} \%)\end{array}$ & $\begin{array}{c}\text { Average } \\
\mathrm{x}\end{array}$ \\
Role play games & $8(5 \%)$ & $85(48 \%)$ & $84(47 \%)$ & $177(100 \%)$ & 2.4 \\
Games with rules & $8(5 \%)$ & $108(61 \%)$ & $61(34 \%)$ & $177(100 \%)$ & 2.3 \\
Constructive games & $62(35 \%)$ & $107(60 \%)$ & $8(5 \%)$ & $177(100 \%)$ & 1.7 \\
\hline
\end{tabular}




\subsection{The Results of Social Studies Teaching Observations}

As seen in Figure 1, when observing 56 lessons of social science where we monitored the use of didactic games, we perceived use of didactic games only in 6 lessons, which represents $11 \%$ of all observed lessons. In 50 observed lessons $(89 \%)$ the teachers of the $4^{\text {th }}$ and $5^{\text {th }}$ grade did not perform a didactic game.

From the Table 4 we can see that none of those 6 teachers used a construction game. 2 teachers (33\%) used a role-playing game and 4 teachers $(67 \%)$ used a game with rules.

Teacher used following games:

1) Games with rules:

Four teachers, who used this type of didactic game, made a quiz adjusted to the theme discussed in a particular lesson. There were different quiz typesgroup or in pair, using PowerPoint or moving in the classroom. Every quiz type had its own rules that students had to follow. At the end of the quiz, the winners were announced.

2) Role-playing games

During the two lessons, two of the teachers used a role-playing game that was adjusted to the theme discussed in the classroom. In the first hour of the role-playing game, students returned to the past and discussed the life of the Romans. In the second hour, they discussed and recreated the life of medieval nobles.

Results also show that in regards to the source of didactic games which were used in Social Studies classes all the games were created and made by the teachers themselves.

Table 3. Frequency of use of role-playing in regards to grade teachers are teaching.

\begin{tabular}{|c|c|c|c|c|c|c|c|}
\hline & & & Freque & $\begin{array}{r}\text { of use of } \\
\text { games }\end{array}$ & ole-playing & Total & \multirow{8}{*}{$\begin{array}{c}\begin{array}{c}\text { Result of } \\
\chi^{2} \text {-test } \\
\chi^{2}=8,597 \\
\mathrm{~g}=2 \\
P=0,014\end{array}\end{array}$} \\
\hline & & & Never & Rarely & Frequently & & \\
\hline \multirow{4}{*}{ Grade } & \multirow{2}{*}{ Fourth grade } & f & 1 & 41 & 51 & 93 & \\
\hline & & $\mathrm{f} \%$ & $1.1 \%$ & $44.1 \%$ & $54.8 \%$ & $100 \%$ & \\
\hline & \multirow{2}{*}{ Fifth grade } & $\mathrm{f}$ & 7 & 44 & 33 & 84 & \\
\hline & & $\mathrm{f} \%$ & $8.3 \%$ & $52.4 \%$ & $39.3 \%$ & $100 \%$ & \\
\hline \multirow{2}{*}{\multicolumn{2}{|c|}{ Total }} & $\mathrm{f}$ & 8 & 85 & 84 & 177 & \\
\hline & & $\mathrm{f} \%$ & $5 \%$ & $48 \%$ & $47 \%$ & $100 \%$ & \\
\hline
\end{tabular}

Table 4. Frequency of use of different types of didactic games in observed lessons.

\begin{tabular}{ccc}
\hline Type of didactic game & f & f\% \\
\hline Role playing & 2 & $33 \%$ \\
Games with rules & 4 & $67 \%$ \\
Construction games & 0 & $0 \%$ \\
Total & 6 & $100 \%$ \\
\hline
\end{tabular}


The pattern of observed teachers is not representative, but it is still helpful in the interpretation of our quantitative research and provides added value to our study of the representation of didactic games in teaching social studies.

\subsection{The Origin of Didactic Games Used in the Subject Social Studies}

Teachers were asked where they most commonly acquire didactic games for social studies.

From the Table 5 we can see that most teachers (44\%) responded that they get didactic games from websites. $31 \%$ of teachers frequently make didactic game themselves, $18 \%$ of teachers find didactic games in teacher's guidebooks and only $4 \%$ of teachers in textbooks. $3 \%$ of teachers responded that they do it by the combination of all possible answers and make use of resources provided by the library.

Given that teachers often create didactic games themselves, we wanted to know how many of them had ever made any didactic game for social studies.

From the Figure 2 we can see that $68 \%$ of the teachers responded that they had already made or prepared a didactic game for social studies.

Among the games they created were most commonly mentioned versions of familiar games, such as quiz, memory, dominoes, cards, board games and puzzles. Teachers explain that they adapt the game already known according to the subject matter and the goal they want to achieve with the game. As we have

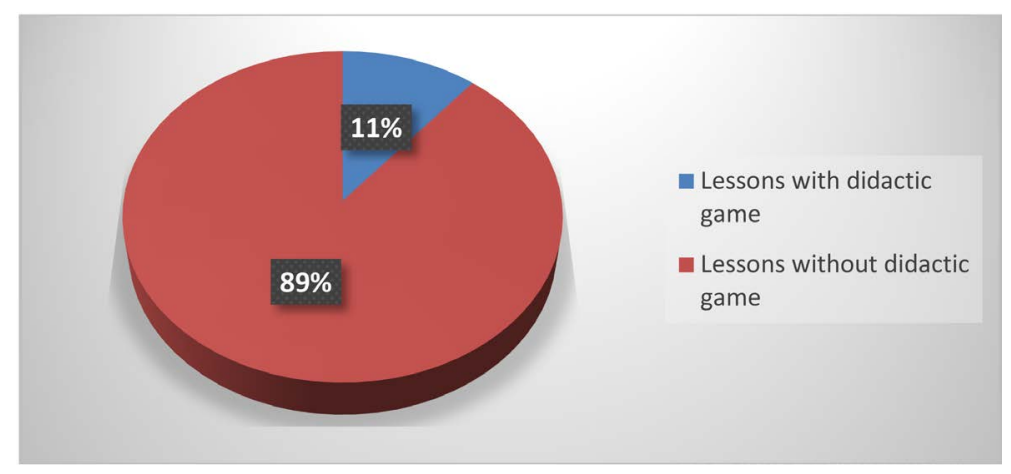

Figure 1. Frequency (f\%) of use of didactic games in observed lessons.

Table 5. Origin of didactic games used in social studies.

\begin{tabular}{ccc}
\hline Answers & f & f\% \\
\hline I create and made didactic game by myself. & 55 & $31 \%$ \\
In textbooks. & 7 & $4 \%$ \\
In teachers guidebooks. & 32 & $18 \%$ \\
On web pages. & 78 & $44 \%$ \\
Other. & 5 & $3 \%$ \\
Total & 177 & $100 \%$ \\
\hline
\end{tabular}




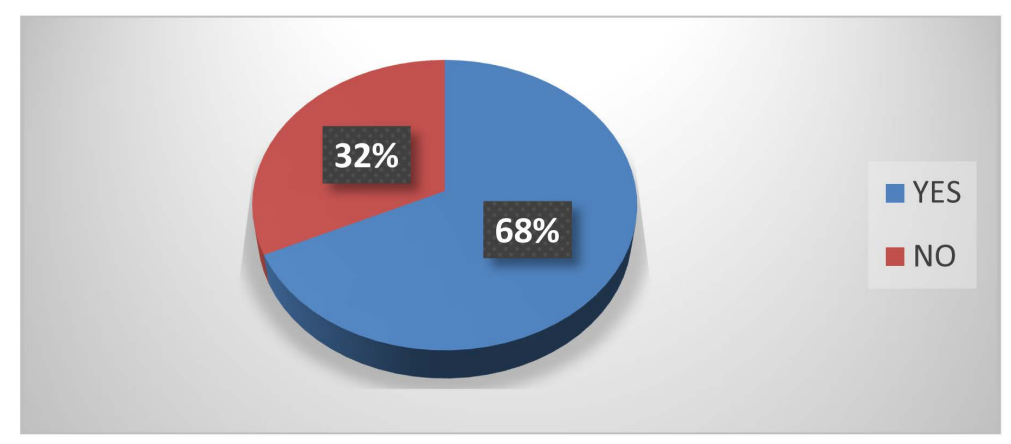

Figure 2. Frequency (f\%) of teachers regarding if they ever created and made a didactic game for social studies.

already mentioned above, all the teachers whose lessons we observed and who used didactic games, produced games themselves.

Due to the fact that teachers have very scarce set of didactic games which can be adapted to teaching social studies available and therefore they have to be very resourceful and creative, we asked them if they want any additional training for game-based learning.

From the Table 6 we can see that $77 \%$ of teachers responded positively and therefore we can conclude that majority of teachers would like to have some kind of additional training for teaching with didactic games. Only $23 \%$ of teachers in research sample replied that they do not need any additional training. This information is important for the planners of training for teachers, because it can help in planning training courses for teachers in practice.

\section{Discussion}

In this article we focused on the part of a wider research about the use of didactic games in the classroom, with the focus on the origin and the sufficiency of didactic games in social studies. Using the qualitative and quantitative empirical research we determined, that teachers rarely use didactic games in teaching social studies. Depending on the type of a game, the most commonly used one is a role-playing game. A role-playing game presents an event, activity, or situation from real life (Bognar, 1987; Marjanovič Umek \& Zupančič, 2001). A role-playing game is in the National Curriculum proposed as a special didactic recommendation for teaching social studies in the fourth and fifth grade of primary school (Budnar et al., 2011). As written in introduction, positive benefits of games on a students' social/emotional, physical and cognitive development have already been well-researched and documented. Some authors presenting positive benefits of play are Bognar (1987), Roskos \& Christie (2000), Ginsburg (2007), and Miller \& Almon (2009).

In lessons observed there were only $11 \%$ of teachers who were using didactic games. All of the games were made by them. The literature review, the answers of the teachers and the lesson observation, have served to highlight the problem of insufficient range of ready-to-use or ready-made games designed for the 
Table 6. Frequency of teachers answers about their wish for additional training for teaching with didactic games.

\begin{tabular}{ccc}
\hline Answers & f & f\% \\
\hline Yes & 136 & $77 \%$ \\
No & 41 & $23 \%$ \\
Total & 177 & $100 \%$ \\
\hline
\end{tabular}

subject social studies. As a result, teachers are forced to invent their own didactic games, if they want to use them in the classroom.

Most teachers answered that they would like to be further trained in using games for teaching social science, so this is an important piece of information for planners of training for teachers. Professional education and training of teachers should reflect the needs of the employed staff, and it has to be, therefore, adjusted to the circumstances in practice. Our research can assist in the planning of lessons in social science and training courses for teachers and prospective teachers of the subject social studies in primary school.

\section{Conclusion}

Results of our quantitative and qualitative empirical research on the representation of didactic games offer an overview on the use of didactic games in social studies. In future, it would be reasonable to upgrade our research with a pedagogical experiment, where we would be able to measure the actual effect of didactical games contribution in all dimensions of learning objectives-cognitive, conative and psychomotor.

According to the results of our research, teachers create the majority of didactic games by themselves. This can be considered as an important research outcome, since consequently we can suggest that it would be reasonable to make and organize a collection of didactical games in social studies that would facilitate learning process and save time.

\section{References}

Bodrova, E., \& Leong, D. (2007). Play and Early Literacy: A Vygotskian Approach. In K. A. Roskos, \& J. F. Christie (Eds.), Play and Literacy in Early Childhood (2nd ed.). Mahwah, NJ: Lawrence Erlbaum Associates.

Bognar, L. (1987). Igrapripoukunazačetkušolanja. [Game at the Beginning of School Education]. Ljubljana: DZS.

Boocock, S. S. (1972). An Introduction to the Sociology of Learning. New York: Houghton Mifflin.

Budnar, M., Kerin, M., Umek, M., Raztresen, M., \& Mirt, G. (2011). Učninačrt. Program osnovnašola. Družba. [Primary School Curriculum for Social Studies]. Ljubljana: Ministrstvozašolstvo in šport, Zavod RS zašolstvo.

Cenčič, M, Cotič, M., \& MedvedUdovič, V. (2008). Pouk v družbiznanja. In V. Medved Udovič, M. Cotič, \& M. Cenčič, (Eds.), Sodobnestrategijeučenja in poučevanja. [Modern Didactic Teaching and Learning Strategies] (pp. 283-308). Koper: Pedagoškafa- 
kulteta.

Cramer, D., \& Howitt, D. L. (2004). The SAGE Dictionary of Statistics: A Practical Resource for Students in Social Sciences. London: SAGE Publications Ltd. https://doi.org/10.4135/9780857020123

Field, A. (2013). Discovering Statistics Using IBM SPSS Statistics (4th ed.). London: SAGE Publications Ltd.

Ginsburg, K. (2007). The Importance of Play in Promoting Healthy Child Development and Maintaining Strong Parent-Child Bonds. Pediatrics, 119, 182-191. https://doi.org/10.1542/peds.2006-2697

Juriševič, M. (2012). Motiviranjeučencev v šoli. [Students Motivation at School]. Ljubljana: Pedagoškafakulteta.

Marentič Požarnik, B. (2003). Psihologijaučenja in pouka. [Psychology of Learning and Teaching]. Ljubljana: DZS.

Marjanovič Umek, L., \& Zupančič, M. (2001). Teorijaotroškeigre. In L. Marjanovič Umek, \& M. Zupančič (Eds.), Psihologijaotroškeigre. Od rojstva do vstopa $v$ šolo. [Children Play Psychology] (pp. 1-33). Ljubljana: Znanstveni inštitut Filozofske fakultete.

Martin, D. J. (2001). Constructing Early Childhood Science. Albany, NY: Delmar Thomson Learning.

Maxim, G. W. (2010). Dynamic Social Studies for Constructivist Classrooms. Boston: Pearson Education, Inc.

Miller, E., \& Almon, J. (2009). Crisis in the Kindergarten: Why Children Need to Play in School. College Park: Alliance for Childhood.

Naude, L., Bergh, T., \& Kruger, I. (2014). "Learning to Like Learning”: An Appreciative Inquiry into Emotions in Education. Social Psychology of Education, 17, 211-228. https://doi.org/10.1007/s11218-014-9247-9

Roskos, K. A., \& Christie, J. F. (2000). Play and Literacy in Early Childhood: Research from Multiple Perspectives. Mahwah, NJ: Lawrence Erlbaum Associates Publishers.

Sawyer, R. K. (2001). Play as Improvisational Rehearsal: Multiple Levels of Analysis in Children's Play. In A. Göncü, \& E. Klein (Eds.), Children in Play, Story, and School (pp. 19-38). New York, NY: Guilford.

Smilansky, S. (1968). The Effects of Sociodramatic Play on Disadvantaged Preschool Children. New York, NY: John Wiley \& Sons.

Smith, P. K., \& Simon, T. (1984). Object Play, Problem-Solving and Creativity in Children. In P. K. Smith (Ed.), Play in Animals and Humans (pp. 199-216). Oxford: Basil Blackwell, Inc.

Tankersley, D., Brajković, S., Handžar, S., Rimkiene, R., Sabaliauskiene, R., Trikiž, Z., \& Vonta, T. (2013). Od teorije k praksi. In M. Režek (Ed.), Putting Knowledge into Practice. A Guidebook for Educators of ISSA'a Principles of Quality Pedagogy. Ljubljana: Pedagoškiinštitut.

Tomić, A. (1999). Izbranapoglavjaizdidaktike. [Selected chapters from didactics]. Ljubljana: Centerzapedadoškoizobraževanje Filozofskefakultete.

Wurdinger, S. D., \& Carlson, J. A. (2010). Teaching for Experiential Learning: Five Approaches That Work. Lanham, MD: Rowman and Littlefield Education. 
Submit or recommend next manuscript to SCIRP and we will provide best service for you:

Accepting pre-submission inquiries through Email, Facebook, LinkedIn, Twitter, etc. A wide selection of journals (inclusive of 9 subjects, more than 200 journals)

Providing 24-hour high-quality service

User-friendly online submission system

Fair and swift peer-review system

Efficient typesetting and proofreading procedure

Display of the result of downloads and visits, as well as the number of cited articles Maximum dissemination of your research work

Submit your manuscript at: http://papersubmission.scirp.org/

Or contact ce@scirp.org 